\title{
Application of sequencing batch reactor (SBR) for treatment of refinery wastewater containing nickel
}

\author{
A. Malakahmad, S. Ishak, U. N. Nasoha, M. H. Isa \& S. R. Kutty \\ Department of Civil Engineering, \\ Universiti Teknologi PETRONAS, Malaysia
}

\begin{abstract}
A petroleum refinery is a complex combination of interdependent industrial processes that generate wastewater effluent containing hydrocarbons, heavy metals and dissolved minerals which cause harmful effects to human and environment. While physicochemical systems are widely accepted as effective methods for treatment of industrial wastewater, biological processes are beginning to play an increasing role in the treatment of metal containing effluents. The objective of the present study is to investigate the biological treatment of refinery wastewater containing nickel. The SBR performance was assessed by measuring Chemical Oxygen Demand (COD), Mixed Liquor Suspended Solid (MLSS), Mixed Liquor Volatile Suspended Solid (MLVSS) as well as nickel concentrations. The SBR was operated on a 12-hour cycle basis which consisted of five distinct modes: fill, react, settle, draw, and idle. The wastewater was brought from an equalization tank of a refinery plant and was fed to the reactor after characterization. The nickel concentration ranged from 2.3 to $2.6 \mathrm{mg} / \mathrm{L}$. The experimental results demonstrate COD and nickel removal efficiencies of $70-90 \%$ and $77-80 \%$, respectively. Keywords: refinery wastewater, sequencing batch reactor, nickel.
\end{abstract}

\section{Introduction}

Large amounts of water are being utilized in petroleum refinery industry for cooling, desalting and dehydration processes [1,2]. Refining process generate wastewater 0.4-1.6 times the volume of crude oil processed [1]. The most important pollutants are hydrocarbons, phenol and dissolved minerals that are 
referred as priority pollutants [3], $80 \%$ of which may be considered hazardous because of the presence of toxic organics and heavy metals such as nickel even at very low concentrations $[2,4]$.

Nickel is one of the toxic heavy metals present in petroleum refinery wastewater [4, 5]. Nickel is commonly found in crude oils and need to be removed due to its ability to poison the catalysts activities in refining process [6]. In addition, residual feedstock at fluidized bed catalytic cracking units have higher metals content especially nickel and greater coke forming potential than distillate feeds. This contaminant reduces catalysts activity, promotes coke and hydrogen formation and leads to decrease gasoline yield due to its deposition on the catalyst [7]. Discharge of untreated petroleum refinery wastewater containing nickel into water bodies results in environmental and human health problems [5]. Accumulation of nickel in the body can cause lung fibrosis, cardiovascular, kidney diseases and act as carcinogenic agent [8-10]. Excessive concentrations of nickel in water affect the living organism's growth such as algae [10].

Studies conducted on wastewater treatment containing heavy metals using chemical precipitation, coagulation-flocculation, flotation, membrane filtration and ion exchange indicated that these technologies are costly and produce excessive sludge $[3,4,12]$. Biological wastewater treatment systems are rapidly gaining support as the option is being shown to be technologically and economically feasible $[11,12]$. Biological system is simple to operate and cost effective due to the use of microorganisms. Microorganisms play an important role in oxidizing dissolved and particulate carbonaceous organic matter into simple end products.

SBR is a biological method that has several advantages compared to the activated sludge process. Application of SBR is feasible since the system operates in a simple tank and the need of a clarifier is eliminated. Moreover, SBR system is also flexible in operation, controllable in reaction time and has perfect quiescent settling [13-15]. SBR gives high efficiency in Biochemical Oxygen Demand (BOD) and Suspended Solid (SS) removal (89-98\% and 85$97 \%$, respectively) [14].

The objective of this research is to evaluate the performance of SBR in presence of nickel in refinery wastewater treatment.

\section{Materials and methods}

\subsection{Sampling procedures}

Refinery wastewater was collected from equalization tank unit. It was then brought to the university Environmental Engineering Laboratory and stored in a cool room at $4^{\circ} \mathrm{C}$. A portion of the sample was brought to room temperature and analyzed for $\mathrm{COD}, \mathrm{BOD}_{5}, \mathrm{TSS}, \mathrm{pH}$, turbidity, alkalinity, colour, nitrate, phosphorus, ammonia nitrogen, phenol, sulphide, sulphate and nickel. Analyses were conducted based on Standard Method for the Examination of Water and Wastewater [16]. $\mathrm{pH}$ and turbidity were measured using a $\mathrm{pH}$ meter (HACH sension 4) and a turbidimeter (HACH 2100P). Dissolved oxygen (DO) was 
measured using a DO meter (YSI Incorporated, Model: YSI 5000, USA). The performance of SBR was monitored by measuring the COD, MLSS, MLVSS and nickel concentrations. Analyses were carried out in triplicate and the standard deviation was calculated respectively.

\subsection{Seeding materials}

The SBR was started with the adding of seed sludge collected from treatment facility of same refinery plant for faster start-up. The volume of seed sludge added to the system was based on $F / M$ ratio as in eqns (1) and (2).

$$
\begin{gathered}
Q=V_{\text {in }} \cdot N_{\text {cycle }} \\
F / M=\frac{Q \cdot C O D_{i n}}{V \cdot M L V S S}
\end{gathered}
$$

where $Q$ is the wastewater flow rate $(\mathrm{L} / \mathrm{d}), V_{\text {in }}$ is the influent feed volume per cycle (L/cycle), $N_{\text {cycle }}$ is the number of cycle per day, $V$ is the volume of the SBR (L) and MLVSS is the sludge concentration in the reactor $(\mathrm{mg} / \mathrm{L})$.

\subsection{Experimental setup}

SBR was operated using a fill and draw periodic system with a total working volume of $4 \mathrm{~L}$. The reactor was seeded with sludge and fed with wastewater from the equalization tank. The SBR was operated on a $12 \mathrm{~h}$ cycle basis which composed of fill (15 min.), reaction (585 min.), settle (60 min.), draw (15 min.) and idle (45 min.). An aquarium pump (Hailea ACO-9610, China) was used in the system to supply sufficient air to the reactor with an air flow rate of 4.5 L/min. All experiments were carried out at room temperature. Fig.1 illustrates the schematic diagram of the SBR.

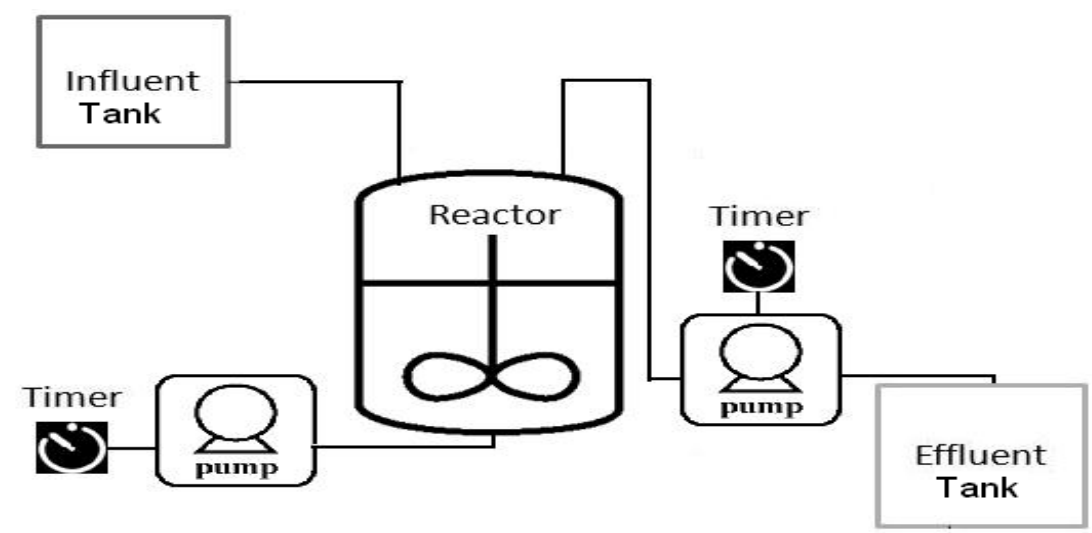

Figure 1: Schematic diagram of the SBR. 


\section{Results and discussion}

\subsection{Refinery wastewater characteristics}

Table 1 shows the petroleum refinery wastewater characteristics. The results indicate a low $\mathrm{BOD}_{5}$ of $94.1 \pm 3.80 . \mathrm{BOD}_{5}$ for refinery wastewater is lower than municipal wastewater due to small concentration of organic materials that are partially biodegradable [17]. A study conducted by Misbahudin et al. also reported low $\mathrm{BOD}_{5}$ in petrochemical wastewater [18]. Both $\mathrm{COD}$ and nickel concentrations ( $405 \pm 11.59$ and $2.3 \pm 0.01$, respectively) exceeded Standard B by Department of Environmental Malaysia (DOE); stipulated in Environmental Quality Act 1974 and the Environmental Quality Regulations (Sewage and Industrial Effluents) 2009 [19]. According to DOE Standard B, the allowable concentrations for COD and nickel are 100 and $1.0 \mathrm{mg} / \mathrm{L}$ respectively. In addition, other parameters such as ammonia nitrogen, colour, sulphide and phenol also exceeded DOE Standard B.

Table 1: $\quad$ Petroleum refinery wastewater characteristics.

\begin{tabular}{|l|c|c|c|}
\hline Parameters & Units & Values & Standard B \\
\hline $\mathrm{BOD}_{5}$ & $\mathrm{mg} / \mathrm{L}$ & $94.1 \pm 3.80$ & 50 \\
\hline $\mathrm{COD}$ & $\mathrm{mg} / \mathrm{L}$ & $405 \pm 11.59$ & 200 \\
\hline $\mathrm{pH}$ & - & $9.4 \pm 0.01$ & $5.5-9.0$ \\
\hline Turbidity & $\mathrm{NTU}$ & $38.2 \pm 0.81$ & - \\
\hline Alkalinity & $\mathrm{CaCO}$ & $657 \pm 13.01$ & - \\
\hline Color & $\mathrm{Pt} \mathrm{Co}$ & $133 \pm 3.05$ & 200 \\
\hline TSS & $\mathrm{mg} / \mathrm{L}$ & $104.3 \pm 2.08$ & 100 \\
\hline Nitrate & $\mathrm{mg} / \mathrm{L}$ & $3.7 \pm 1.10$ & - \\
\hline $\begin{array}{l}\text { Ammonia } \\
\text { nitrogen }\end{array}$ & $\mathrm{mg} / \mathrm{L}$ & $13.8 \pm 0.42$ & 20 \\
\hline Phosphorus & $\mathrm{mg} / \mathrm{L}$ & $1.7 \pm 0.03$ & - \\
\hline Sulphide & $\mathrm{mg} / \mathrm{L}$ & $0.163 \pm 6.66$ & 0.5 \\
\hline Sulphate & $\mathrm{mg} / \mathrm{L}$ & $43 \pm 5.77$ & - \\
\hline Nickel & $\mathrm{mg} / \mathrm{L}$ & $2.3 \pm 0.01$ & 1.0 \\
\hline Phenol & $\mathrm{mg} / \mathrm{L}$ & $5.73 \pm 1.15$ & 1.0 \\
\hline
\end{tabular}

\subsection{COD analysis}

SBR was operated and its performance was monitored for 77 days based on COD analyses. At start-up of SBR, wastewater was mixed with seed materials and being acclimatized. Acclimation period is necessary in order to expose the microbial community to the potentially inhibitory or toxic organic compounds 
present in wastewater [20]. Moreover, acclimatization period is important for development of metabolic systems such as appropriate enzyme-producing genes that are essential to encourage biodegradation [11, 20, 21]. The final COD concentration and COD removal efficiency are shown in fig. 2.

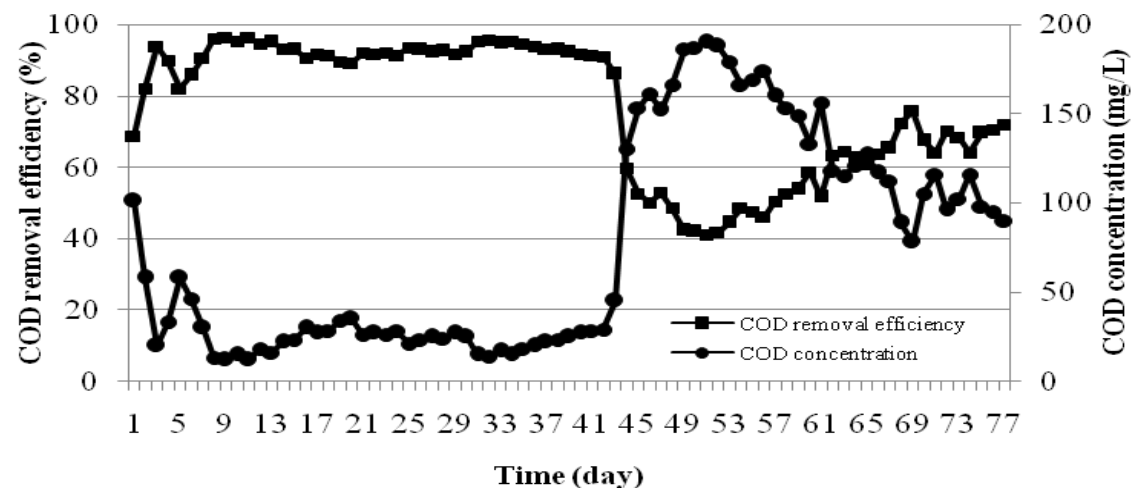

Figure 2: $\quad$ Final COD concentration and COD removal efficiency (\%).

From the beginning until day 9, the system was unstable based on fluctuation of COD concentration. This shows that the microorganisms were still not able to adapt with the new environment. From day 10 to 42, COD removal efficiency started to gradually reach constant values. Adaptation of microorganisms to the system can be indicated by monitoring effluent COD which is reaching constant values [13]. This indicates that microorganisms in the system have acclimatized after day 9 and the SBR is ready to receive higher nickel dosage. Therefore, nickel concentration which was $2.3 \mathrm{mg} / \mathrm{L}$ at the beginning was increased to $2.4 \mathrm{mg} / \mathrm{L}$ on day 43 and 2.6 on day 60 after achieving steady state conditions in the system. Addition of $2.4 \mathrm{mg} / \mathrm{L}$ and $2.6 \mathrm{mg} / \mathrm{L}$ higher nickel dosage leads to decreased COD removal efficiency in both dosages. Relatively low concentration of heavy metals may serve to stimulate biological systems. However, any increase in concentration of toxic materials may decrease stimulation and eventually result in the system becoming inhibited $[15,22]$. While, nickel with concentrations of 2.4 and $2.6 \mathrm{mg} / \mathrm{L}$ were introduced to the system, acclimatization was achieved based on COD removal efficiency after each increment in nickel concentration. However, the system was not able to produce less polluted effluent as compared to the duration where it was operated with lower nickel dosage. It shows that after receiving a higher dosage, the system becomes inhibited and decreases COD removal efficiency. Overall, the final COD concentration met DOE Standard B.

\subsection{MLSS and MLVSS analysis}

MLSS and MLVSS were analyzed to measure the microorganism's concentration in the system. MLSS indicates the presence of volatile and inert 
solids in the sludge. MLVSS closely approximates the biologically active portion of the solid in the sludge [11]. Chan et al. [13] reported that the acclimatization phase might be achieved when the MLVSS concentration is increased steadily. This trend reflects the active growth of bacteria which indicates the success of adaptation [13]. The bacteria utilize organic matters and multiply to form new cells. An adequate MLVSS concentration has to be maintained to ensure sufficient biomass concentration for biological reactions. Process operations with low MLVSS will lead to poor bio-flocculation, inadequate entrapment of particulate organic matter and bad settling of activated sludge [23]. Results shown in fig. 3 indicate stable MLVSS concentration throughout the experiment. It was due to proper selection of $F / M$ ratio and perhaps high concentration of acclimatized microorganisms in the collected sludge from refinery wastewater treatment plant. However, decrease in MLSS and MLVSS concentration at certain days on nickel addition to the SBR affects SBR system performances.

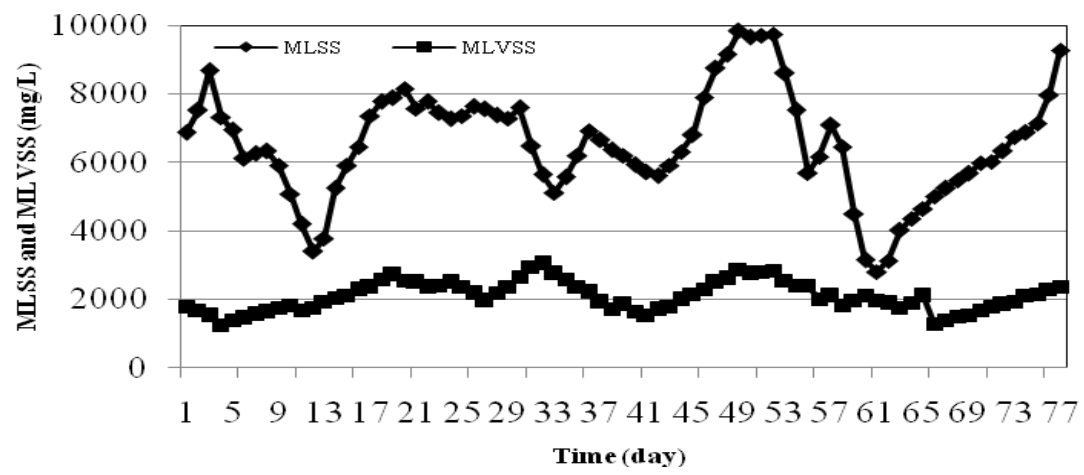

Figure 3: $\quad$ MLSS and MLVSS concentration.

\subsection{Nickel removal}

The SBR system reduces nickel concentration ranging from 0.48 to $0.53 \mathrm{mg} / \mathrm{L}$ $(78.7 \%)$ and from 0.53 to $0.55 \mathrm{mg} / \mathrm{L}(79.2 \%)$ for nickel's initial concentration of 2.4 and $2.6 \mathrm{mg} / \mathrm{L}$, respectively. Results of final nickel concentration and its removal efficiency (\%) are shown in fig. 4. Nickel removal efficiency dropped after introduction of higher nickel dosage. Studies reported on the same trend as microorganisms are affected with the addition of higher nickel dosage leads to decrease of nickel removal efficiency. However, nickel removal efficiency will start to increase once the microorganisms are adapted with new higher nickel dosage [24-26]. Final nickel concentration was below $1.0 \mathrm{mg} / \mathrm{L}$ which meets the DOE Standard B discharge limit. 


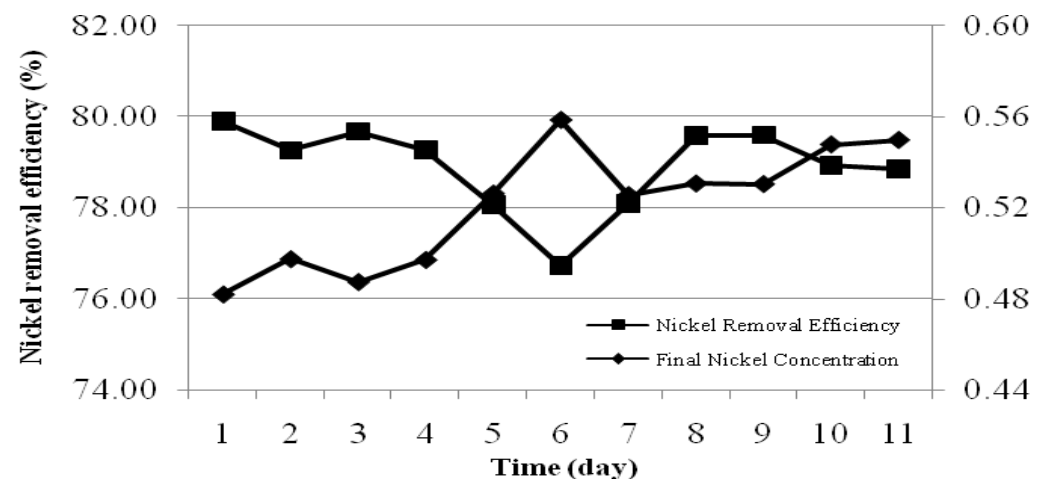

Figure 4: $\quad$ Final concentration of nickel and nickel removal efficiency (\%).

\section{Conclusions}

Physicochemical treatments of wastewater have been used vastly for heavy metals removal such as nickel. However, those treatments involve high cost and production of excessive sludge. Biological systems are suitable choice as they are cheap and have high efficiency of contaminants removal efficiency. SBR systems require small space since no clarifiers are required. SBR has shown successful performance of COD removal efficiency ranging from $70 \%$ to $90 \%$ and nickel removal efficiency are found to be up to $79.2 \%$ in refinery wastewater. This study verifies that SBR is suitable system for heavy metals removal i.e. nickel.

\section{Acknowledgement}

This paper was supported by Universiti Teknologi PETRONAS (project code: STIRF No. 07/09.10). The cooperation of the management and authorities of the university with authors is fully appreciated.

\section{References}

[1] Coelho, A., Castro, A.V., Dezotti, M. and Sant' Anna, G.L. Jr., Treatment of petroleum refinery sourwater by advanced oxidation processes. Journal of Hazardous Materials, 137, pp. 178-184, 2006.

[2] Moulin, J.A., Makkee, M. and Diepen, A.V., Chemical Process Technology, John Wiley and Sons Ltd, 2001.

[3] Hami, M.L., Al-Hashimi, M.A. and Al-Doori, M.M., Effect of activated carbon on BOD and COD removal in a dissolved air flotation unit treating refinery wastewater. Desalination, 216, pp. 116-122, 2007.

[4] Xu, H., Liu, Y. and Tay, J.H., Effect of $\mathrm{pH}$ on nickel biosorption by aerobic granular sludge. Bioresource Technology, 97(3), pp. 359-363, 2006. 
[5] Duman, F. and Ozturk, F., Nickel accumulation and its effect on biomass, protein content and antioxidative enzymes in roots and leaves of watercress. Journal of Environmental Sciences, 22(4), pp. 526-532, 2010.

[6] Rathi, R., Petroleum Refining Technology, SBS Publisher and Distributors Pvt. Ltd, New York, 2007.

[7] Gary, J.H., Handwerk, G.E. and Kaiser, M.J., Petroleum refining: technology and economics", 5th ed. Boca Raton: CRC Press, pp. 1-2, 2007.

[8] Jo, M.S., Rene, E.R., Kim, S.H. and Park, H.S., An analysis of synergistic and antagonistic behaviour during BTEX removal in batch system using response surface methodology. Journal of Hazardous Materials, 152, pp. 1276-1284, 2008.

[9] Kasprzak, K.S., Sunderman, F.W. Jr. and Salnikow, K., Nickel carcinogenesis. Mutation Research, 533(1-2), pp. 67-97, 2003.

[10] Dionisi, D., Levantesi, C., Majone, M., Bornoroni, L. and Sanctis, M.D., Effects of micropollutants (organic xenobiotics and heavy metals) on the activated sludge process. Industrial and Engineering Chemical Research, 46(21), pp. 6762-6769, 2007.

[11] Metcalf and Eddy, Wastewater Engineering; Treatment and Reuse, (4 $\left.{ }^{\text {th }} \mathrm{ed}\right)$. McGraw-Hill, Inc., New York, 2004.

[12] Dobson, R.S. and Burgess, J.E., Biological treatment of precious metal refinery wastewater: A review. Minerals Engineering, 20, pp. 519-532, 2007.

[13] Chan, Y.J., Chong, M.F. and Law, C.L., Biological treatment of anaerobically digested palm oil mill effluent (POME) using a lab-scale Sequencing Batch Reactor (SBR). Journal of Environmental Management, 91, pp. 1738-1746, 2010.

[14] Mahvi, A.H, Sequencing batch reactor: a promising technology in wastewater treatment. Iranian Journal of Environment Health Science and Engineering, 5, pp. 79-90, 2008.

[15] Malakahmad, A., Hasani, A., Eisakhani, M. and Isa, M.H., Sequencing Batch Reactor (SBR) for the removal of $\mathrm{Hg}^{2+}$ and $\mathrm{Cd}^{2+}$ from synthetic petrochemical factory wastewater. Journal of Hazardous Materials, 191, pp. 118-125, 2011.

[16] APHA, AWWA, WPCF, Standard methods for the examination of water and wastewater, $\left(21^{\text {st }}\right.$ ed.), American Public Health Association, American Water Works Association, Water Pollution Control Federation, Washington, DC, USA, 2005.

[17] Al Zarooni, M. and Elshornagy, W., Characterization and assessment of Al Ruwais refinery wastewater. Journal of Hazardous Materials, 136(3), pp. 398-405, 2006.

[18] Misbahuddin, M. and Farooq, S., Biological treatment of petrochemical wastewater using SBR. Environmental Technology, 12, pp. 69-70, 1991.

[19] Environmental Quality (Sewage and industrial Effluents) Regulations (1979) Percetakan Nasional Berhad, 2009. 
[20] Fongsatitkul, P., Elefsiniotis, P. and Yamasmit, N., Use of Sequencing Batch Reactors and Fenton reagent to treat wastewater from textile industry. Biochemical Engineering, 21, pp. 213-220, 2004.

[21] Moreno, I. and Buitron, G., Evolution of the microbial activity during the acclimation and deacclimation (starvation) of activated sludge to 4chlorophenol, $4^{\text {th }}$ IWA World Water Congress, Mawakech, 2004.

[22] Babgy, M.M. and Sherrard, J.H., Combined effects of cadmium and nickel on the activated sludge process. Journal Water Pollution Control Federation, 53, pp. 1609-1619, 1981.

[23] Ng, J.W., Industrial Wastewater Treatment, World Scientific Publishing Company, 2006.

[24] Chua, H. and Hua, F.L., Effects of heavy metals (zinc) on organic adsorption capacity and organic removal in activated sludge. Applied Biochemistry and Biotechnology, 57-58, pp. 845-849, 2010.

[25] Ong, S-An, Toorisaka, E., Hirata, M. and Hano, T., Effects of nickel (II) addition on the activity of activated sludge microorganisms and activated sludge process. Journal of Hazardous Materials, 10, pp. 111-121, 2004.

[26] Gikas, P., Single and combined effects of nickel and cobalt ions on activated sludge and on other aerobic microorganism: a review. Journal of Hazardous Materials, 159, pp. 187-203, 2008. 